\title{
A Trend towards Integrating Information Literacy into the Curriculum and Its Implications to Academic Settings in Vietnam
}

\author{
Pham Xuan Hoan \\ International School - Vietnam National University \\ Library Centre, Building C, HACINCO Student Village, 99 Nguy Nhu Kon Tum, \\ Thanh Xuan, Hanoi, Vietnam \\ Email: pxhoan@isvnu.vn/pxhoan@gmail.com
}

\begin{abstract}
This secondary research explored the challenges associated with information literacy (IL) integration into the curriculum, and suggested strategies to develop holistic IL programs for education institutions in Vietnam and more beyond. The meta-synthesis method was employed to gather qualitative data and then synthesize them to make more sense of IL integration research evidence. Four research questions were formulated to frame the study. Research findings indicated eight challenges including management support, stakeholder's perceptions of IL integration, librarian's capacity, IL assessment methods, facultylibrarian collaboration, learning and teaching methods, IL training contents, and curriculum overload. Accordingly, six strategies which comprise: top-down management approach, assignment design, IL assessment, capacity building for IL trainers, strengthening the faculty-librarian collaboration, and enriching $\mathrm{IL}$ training contents were proposed to help education institutions to achieve a systematic IL integration into the curriculum. This study also showed the significance of IL integration to the enhancement of student's lifelong learning skills.
\end{abstract}

Key words: Information literacy, integration, curriculum design, Vietnam

\section{Research Background}

\subsection{Research rationale}

Recent studies show that digital content is rapidly increasing and internet search engines such as Google, Yahoo are dominantly used among students (Brophy \& Bawden, 2005; Online Computer Library Center, 2005). In fact, students encounter difficulties in identifying reliable information (Pham, 2012). Given the context, librarians and faculties are expected to provide students with information literacy (IL) training activities to improve their abilities to "identify their information needs, then access, locate, evaluate and synthesize and analyze quality information found in electronic or print based sources" (Hine, Gollin, Ozols, Hill, \& Scoufis, 2002). In the meantime, standalone IL training programs provided by academic libraries hardly meet a huge demand for a large number of students, and the need for a continual support for throughout their academic lives. Integrating IL into the curriculum is considered an essential strategy for education institutions to cope with such changes. However, this initiative has posed a number of challenges to librarians, academics, and other educational stakeholders. This study thus aims to examine current IL integration practices, uncover new challenges, formulate appropriate IL integration strategies, and indicate the significance of IL integration to the enhancement of student's lifelong learning skills. 


\subsection{Research questions}

Based on the research rationale, the following research questions have been formulated:

- To what extent IL integration into the curriculum has been adopted in academic settings in Vietnam and the global context?

- What are common challenges pertain to IL integration into the curriculum in Vietnam and overseas countries?

- How IL integration into the curriculum is significant to the enhancement of student's lifelong learning skills?

- What are specific solutions/strategies to deal with uncovered challenges?

\subsection{Research objectives:}

Overall, research objectives are to find answers to the four research questions. While current IL integration practices are revealed in the Literature Review session, answers to the second and third questions can be found in the Research Findings session. IL integration strategies were finally recommended.

\subsection{Research scope}

- Research contents are limited to IL embedment practices, associated challenges, and solutions/strategies. Contents relating to the significance of IL integration to student's lifelong learning skills was also reviewed. Research objects are those students, librarians, faculty, and managers who deal with information literacy in academic settings in Vietnam and overseas countries.

\section{Literature Rreview}

\subsection{Explanation of IL related concepts}

Information literacy

IL is a big concept, confusing and can be interpreted differently depended on the context. IL was first coined in 1973 (Zurkowski, cited in Kuhlthau, 1987), now it has become "a global concern, and a variety of definitions and models exists" (Jackson \& Durkee, 2008, p. 84). To date, the library and information science has made the most significant influence on the proliferation and implementations of IL cross the globe (Johnson \& Webber, 2003). However, each industry tends to interpret the IL concept in its own voice that best fits its purposes.

The statistic industry approaches to the IL concept as applied skills in everyday life.

According to Australian Bureau of Statistics (1998), IL can be categorized into prose literacy, document literacy, and quantitative literacy. Technological people consider "IL is the use of textual, oral and other data and shared knowledge, to function in society, to achieve one's personal goals, and to develop one's knowledge and potential" (Lankshear \& Knobel, 1998). In the psychological science, IL is understood as individual's abilities of critical thinking and problem-solving (Moore, 2002, p. 2). Meanwhile, Johnson and Webber (2003) supposed that IL employs the theory of information seeking behaviors.

In a broader context, the Prague Declaration stated that IL is not only a "part of the basic human right of lifelong learning", but also a "prerequisite for participating effectively in the Information Society" (The Prague Declaration, 2003, p. 3). Similarly, the Australian Library and Information Association indicated that IL contributes to citizens such as "learning for life; the creation of new knowledge; acquisition of skills; personal, vocational, corporate and organizational empowerment; social illusion; and participative citizenship"(Australian Library and Information Association, 2006).

In the educational sector, American Library Association (ALA) defines IL as "an understanding and set of abilities enabling individuals to recognize when information is needed and have the capacity to locate, evaluate, and use effectively the needed information"(cited in Bundy, 2004, pp 4-5). This study adopts ALA's definition of IL as Parker 
(2003) and Bundy(2004) stated IL is the "use of information in supporting study" and to "address and help resolve personal, job related and broader social issues and problems".

\section{IL integration into curriculum}

IL can be integrated at all levels: institution (graduate attributes), departments (academic policies), course (course objectives), and subject (IL instruction activities) level in academic settings (X. Wang, 2010). For instance, lifelong learning objective is incorporated as one of the core graduate attributes (highest level), or academic policies closely align IL skills with learning objectives and the assessment of student learning outcomes. University of Wollongong stated, IL integration means "curriculum is designed to incrementally develop information literacy skills appropriate to the discipline and future profession". At subject level, IL instruction is an integral part of the curriculum and instruction contents are highlighted in the subject outline (University of Wollongong, 2013). Huffman (2013), however, simply explained that "integration is a method where two or more people work together to provide content".

\subsection{IL integration in the global context}

IL integration has recently been concerned by both researchers and practitioners. It becomes a catalyst for re-engineering core business of academic libraries. A large number of studies on IL integration into the curriculum have been done recently. Legal legitimates, theoretical frameworks, and models have been developed by international library associations and education institutions.

First, the IFLA's Alexandria Proclamation on Information Literacy and Lifelong Learning lies a strong foundation for a global advocacy of IL practices (IFLA, 2005). This highest body of librarianship "urges governments and intergovernmental organizations to pursue policies and programs to promote information literacy and lifelong learning... within the context of the developing information society".

In Australian, American and the UK, the development of three important theoretical IL frameworks/standards has greatly influenced on IL practices in many other countries. The set of six IL standards developed by the Australian and New Zealand Institute for Information Literacy (ANZIIL) and Council of Australian University Librarians (CAUL) emphasized on lifelong learning objective as one of the graduate attributes in higher education institutions. The framework can be used for different purposes such as: 1) principles, standards and practice for IL implementations in all educational sectors, 2) educators rely on this model to develop curriculum objectives, learning outcomes, and assessment criteria, 3 ) in a broader context, it is a guidance for policy development, performance evaluation (Bundy, 2004, p. 7). According to Jackson and Durkee (2008), Australia has a broader approach to IL concept compared to the skills-based approach of America.

In America, the set of five Information Literacy Competency Standards for Higher Education developed by the American Library Association (ALA) in 2000 have now been widely utilized by educational institutions (Jackson \& Durkee, 2008). The America's IL framework, which is similar to the Australia's IL framework, emphasizes on IL as a foundation for lifelong learning, and is central to the mission statements of institutions. The ALA further indicate the rationale for IL practice as a prerequisite for individuals to cope with rapid technological changes and exploitation of information resources.

In the UK, the Seven Pillars of IL model is seen practical to IL practitioners at all educational levels. Different from Australian and American' competency standards, the UK framework stresses on the progress. It is a guideline that helps learners to experience IL learning activities from novice to expert level. 


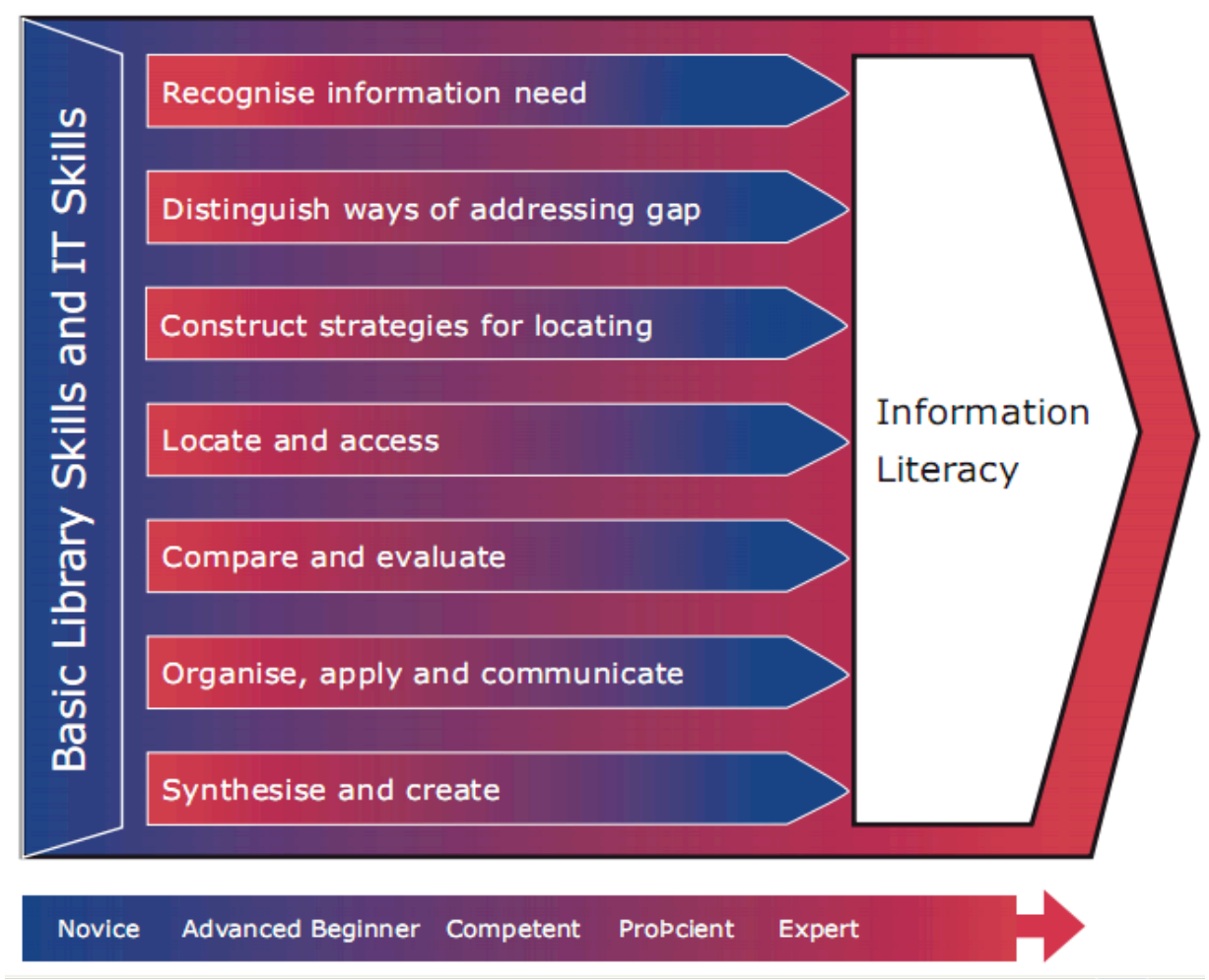

Figure 1: Seven Pillars of Information Literacy Model Source: (SCNUL, 2007)

Recently, a number of universities have initiated IL integration into the curriculum (Monash University Library, 2009; University of Guelph, 2006; University of Wollongong, 2013). At Monash University, a pilot IL integration into the curriculum was implemented for the Faculty of IT in 2006, and then gradually expanded the programs to other faculties. University of Wollongong officially issued an IL Policy, in which purposes, definitions, applications and scope, graduate qualities, IL integration process, activity plan, roles and responsibilities are clearly defined.

Apart from theoretical IL frameworks developed by corporate authors, a large number of practical studies have been done by individual researchers. The majority of authors concentrate on identifying IL integration methods and approaches. Huffman (2013) suggested that institutions to design IL courses for specific disciplines, in which course objectives, contents and skills need to be aligned with IL standards-based criteria identified in the Association of College and Research Libraries (ACRL)'s Information Literacy Competency Standards for Higher Education. Grant \& Berg (2004) considered ACRL Standards as a founding point to appraise students' acquisition of information literacy. The Big6 model mentioned by Huffman (2013) and Derakhshan \& Singh (2011) was suggested to be one of the teaching approaches to deliver IL contents.

Hine et al.(2002) affirmed it is a challenge to develop a holistic and authentic IL integration into the curriculum. This practice requires active involvements of key stakeholders such as teachers, course coordinators, librarians, training program developers, learning skills advisers, and the heads of faculties or departments. Students from various backgrounds need a range of IL skills in information gathering, recognizing relevance, critical thinking, and reflection. 
X. Wang (2010) investigated the characteristics of IL integration, the key stakeholders in IL integration, IL curricular design strategies, and the process of IL curricular integration. The characteristics of IL integration were identified as collaboration and negotiation, contextualization and ongoing interaction with information. X. Wang (2010) insisted, once IL integration is successfully implemented, it "contributes to the development of independent, confident, critical thinking students who were able to meaningfully evaluate and utilize information in a variety of contexts". Derakhshan \& Singh (2011) revealed some common issues namely collaboration, information literacy pedagogy, information literacy skills, and knowledge when conducting a study on academics' views on IL integration. L. Wang (2011) stressed on the essence of a campus-wide multiple-partner collaboration. Issues relating to curriculum, pedagogy and learning theories, information literacy theories, information literacy guidelines, people and collaboration together were examined. The researcher suggested further studies on aligning IL integration with employer's viewpoints on graduate's expected learning outcomes.

To sum up, the literature indicates that IL integration into the curriculum has recently become a more prominent issue in academic settings. The formation of legal legitimates and theoretical frameworks and standards significantly support the both research and implementation purposes. Also, IL policies have been officially reinforced by a certain number of universities. Education institutions identify their own approaches to IL integration into the curriculum. IL can be either aligned with graduate attributes, academic policies, course objectives, IL instruction for subjects, or separate IL courses for specific disciplines.

\subsection{IL integration in the Vietnamese context}

The literature on IL integration in Vietnam was examined by reviewing relevant research papers and investigating IL programs presented on the websites of Vietnamese academic libraries. Since not many studies on IL integration in Vietnam have been done, three important research papers conducted by Diep and Nahl (2011), Nghiem (2006) and Pham (2008) were thoroughly analyzed to identify research gaps as well as problems relating to IL integration in Vietnamese universities.

Diep and Nahl (2011) employed online survey, interview and focus group data collection to investigate the implementations of IL programs in four Vietnamese universities. The study particularly focused on exploring IL practitioner's perceptions, factors needed for IL credit courses as well as potential challenges. In particular, challenges pertain to "the lasting impact of teacher-centered instruction and rote learning, misperceptions about the effect of IL on student learning outcomes, degree of support of by IL academic stakeholders, degree of faculty-librarian collaboration, and scarcity of resources" were identified. Research findings indicates that IL was not perceived widely in those universities. This practice was supposed to be solely librarian's responsibility. IL training activities were conducted in the forms of lectures, workshops, and basic IL skills modules. There existed few IL courses for specific disciplines.

Pham (2008) pointed out a set of challenges that nice surveyed education institutions in Vietnam encountered. The uncovered challenges were lack of top management support, poor librarian-faculty collaboration, staff capacity, poor IL training contents, scarce academic resources, passive learning style, unscientific learning assessment methods, foreign language barriers, and poor library orientations for pupils before entering university level.

Nghiem (2006) conducted a case study research into the IL practice particularly at the College of Social Sciences and Humanities, Vietnam National University. The study analyzed difficulties and then proposed practical solutions to implement of IL training program at CSSH. Interestingly, several common issues were found in Nghiem (2006), Diep and Nahl (2011), and Pham (2008), including "the ignorance of lifelong learning goal within the education mission; domination of teacher-centred teaching and learning method; English 
is not the first language; lack of computer literacy; and neglect of the library and librarians' role. Based on the Australia's IL framework, Nghiem (2006) proposed specific strategies for key actors at institutional; administrative; and implementation planning levels at CSSH.

In short, challenges pertain to the implementation of IL programs at surveyed universities in Vietnam can be summarised as below (Table 1).

Table 1: Challenges facing IL Integration in Vietnamese Universities

\begin{tabular}{|c|c|c|c|}
\hline $\begin{array}{l}\text { Diep and Nahl } \\
(2011)\end{array}$ & Pham (2008) & Nghiem (2006) & $\begin{array}{l}\text { Synthesizing } \\
\text { challenges }\end{array}$ \\
\hline $\begin{array}{l}\text { Degree of support } \\
\text { of IL by academic } \\
\text { stakeholders, }\end{array}$ & $\begin{array}{l}\text { Lack of top } \\
\text { management support }\end{array}$ & $\begin{array}{l}\text { The ignorance of } \\
\text { lifelong learning goal } \\
\text { within the education } \\
\text { mission; }\end{array}$ & Management support \\
\hline \multirow{2}{*}{$\begin{array}{l}\text { Misperceptions } \\
\text { about the effect of } \\
\text { IL on student } \\
\text { learning outcomes, }\end{array}$} & $\begin{array}{l}\text { Inadequate libraries at } \\
\text { the pre university } \\
\text { level. }\end{array}$ & $\begin{array}{l}\text { Neglect of the library } \\
\text { and librarians' role. }\end{array}$ & $\begin{array}{l}\text { Perception of IL } \\
\text { among librarians, } \\
\text { faculties and students }\end{array}$ \\
\hline & Staff capacity & & $\begin{array}{l}\text { Capacity building for } \\
\text { librarians }\end{array}$ \\
\hline \multirow{2}{*}{$\begin{array}{l}\text { Scarcity of } \\
\text { resources. }\end{array}$} & Scarcity of resources & & Scarcity of resources \\
\hline & $\begin{array}{l}\text { IL assessment } \\
\text { methods }\end{array}$ & & $\begin{array}{l}\text { IL assessment } \\
\text { methods }\end{array}$ \\
\hline $\begin{array}{l}\text { Degree of faculty- } \\
\text { librarian } \\
\text { collaboration }\end{array}$ & $\begin{array}{l}\text { Poor librarian-faculty } \\
\text { collaboration }\end{array}$ & & $\begin{array}{l}\text { Librarian-faculty } \\
\text { collaboration } \\
\text { identification of key } \\
\text { stakeholders }\end{array}$ \\
\hline $\begin{array}{l}\text { The lasting impact } \\
\text { of teacher-centered } \\
\text { instruction and rote } \\
\text { learning, }\end{array}$ & $\begin{array}{l}\text { Passive learning } \\
\text { styles }\end{array}$ & $\begin{array}{l}\text { Domination of } \\
\text { teacher-centred } \\
\text { teaching and learning } \\
\text { method; }\end{array}$ & $\begin{array}{l}\text { Teacher-centred } \\
\text { approach, } \\
\text { passive/route learning }\end{array}$ \\
\hline \multirow{2}{*}{$\begin{array}{l}\text { IL activities take } \\
\text { the form of } \\
\text { lectures, } \\
\text { workshops, and } \\
\text { basic IL skills } \\
\text { modules. } \\
\text { Few ILI activities } \\
\text { are subject } \\
\text { discipline-related. }\end{array}$} & $\begin{array}{l}\text { Poor IL training } \\
\text { contents }\end{array}$ & & $\begin{array}{l}\text { Contents and forms of } \\
\text { IL training activities }\end{array}$ \\
\hline & $\begin{array}{l}\text { Foreign language } \\
\text { barriers }\end{array}$ & $\begin{array}{l}\text { English is not the first } \\
\text { language }\end{array}$ & $\begin{array}{l}\text { Foreign language } \\
\text { barriers }\end{array}$ \\
\hline
\end{tabular}

To summarise, academic libraries in Vietnam have voiced their concerns about IL practices. However, little research has been done to uncover insights into the on-site implementations of IL integration. Although Diep and Nahl (2011), Pham (2008) and Nghiem (2006) investigated IL instruction program at 14 education institutions in Vietnam, these studies mainly focused on identifying challenges and proposing recommendations to develop IL training programs. Issues relating IL integration into the curriculum were partly mentioned in these studies. Thus, it is necessary to conduct in-depth research with a specific focus on IL integration into the curriculum appropriate to the context of Vietnamese universities. 


\section{Research Method}

The study approached interpretivism epistemology since the researcher believes that the research topic is a complex phenomenon, socially constructed, and it depends on individual interpretations (Saunders, Lewis, \& Thornhill, 2009). Accordingly, the study employed a deductive approach. Meta-synthesis method was selected as a main instrument to conduct this qualitative and secondary research (Derakhshan \& Singh, 2011).

Recently, the meta-synthesis method has been widely applied in the research area relating to library and information science (Barnett-Page \& Thomas, 2009; Catalano, 2013; Derakhshan \& Singh, 2011; 2009; Paterson, Dubouloz, Chevrier, Ashe, \& Moldoveanu, 2009). According to, Derakhshan \& Singh (2011, p. 219), meta-synthesis "is a method of mixing a group of studies in order to find the common essence in the data and translate that into a new understanding". The method assists with synthesizing qualitative data to make more sense of IL integration research evidence (Duke \& Ward, 2009).

The reasons underpinning the selection of meta-synthesis method derived from the research context. While a greatly deal of studies on IL integration into the curriculum have been done in the global context, this content was partly and indirectly mentioned in recently studies conducted for Vietnamese universities. To conceptualize this phenomenon, a secondary research needs to be done to examine common issues relating to IL integration in Vietnamese university context. Meta-synthesis is thus considered appropriate method in this study.

With regard to the research process, the researcher first formulates research questions, research objectives and research scopes. When needed information was identified, a searching strategy was then developed to locate appropriate academic sources (Emerald, Science Direct, websites of international library associations and universities). Search terms "information literacy", "integration", "embedment" "policy", "standards" "challenges" "strategies" were flexibly combined to conduct advanced searches on online academic databases, Google Scholars and institutions' websites. Common themes distilled from the literature were synthesized into a discussion of IL integration (Catalano, 2013). Issues relating to core concepts, theoretical frameworks and models, IL integration approaches, common challenges and strategies were critically analyzed, synthesized and organized.

\section{Research Findings}

\subsection{Problems/challenges pertain to IL into the curriculum}

The session discusses problems/challenges pertain to IL integration into the curriculum and its significance to learning and teaching activities in Vietnam and overseas countries where possible.

Lack of management support

Problems associated with management support are subject to manager/leader's misperception and lack of commitments to the integration of $\mathrm{IL}$ into the curriculum at all organizational levels. In Australia, although senior academic staff emphasized the importance of IL, and lifelong learning is central to the institution's mission statement, still there was a "gap" between policies, commitments and on-site implementations (Abbott \& Peach, 2000; Bundy, 2004; Feast, 2003). Feast (2003, p. 81) reported the case of University of South Australia, where "there were no significant changes in IL teaching and learning over the 12 months from 2000 - 2001. Action plan has not delivered as the intended outcomes". Similarly, in American universities, ACRL revealed that "In a sampling of 664 campuses of higher education, 185 have a formal IL requirement, and only 22 percent were aware of and apply the IL competency standards for higher education" (cited in Farmer, 2003, p. 311). 
In Vietnam, Diep \& Nahl (2011) and Pham (2008) showed that IL practices have not gained sufficient support in terms of budget allocation, resources and personnel, and concerns from university management boards. Diep \& Nahl (2011, p. 339) further uncovered, "Library administrators and librarians ranked university support as the most challenging factor with $91.6 \%$ reporting it as a great challenge or a challenge, and $85.9 \%$ for faculty". In addition, 95\% librarians reported that IL was not integrated into university and library strategic planning. So that lifelong learning objective was unlikely to be considered one of core graduate attributes in those academic settings.

Perceiving the value of IL integration among librarians, faculties and students According to Bruce (2001), there existed a "gap" between academics and librarians regarding the interpretation of IL meanings. While lecturers, tutors, and course coordinators intended to translate the IL concept differently in particular educational domains, librarians prefer a consistent and concrete one in the university. Few academics did not assume IL is a apart of course objectives (Feast, 2003).

In Vietnam, not many senior staff, librarians and faculties are fully aware of the importance of IL alignment into the curriculum. Diep and Nahl (2011, p. 339) concluded that "Campus leadership, faculty, and students have not recognized the benefits of adopting IL and assessing it in student learning outcomes". The reasons were shortage of communication such as formal campus-wide meetings, or specific strategies to raise awareness among key stakeholders. Nghiem (2006, p. 1) added, "The concept of lifelong learning and information literacy has not been understood comprehensively and accurately at CSSH". These obstacles potentially inhibit the process of aligning IL into the curriculum.

\section{Challenges facing librarians}

IL integration has posed a great deal of challenges to librarians regarding requirements of new knowledge and skills and workloads. To effectively deliver integrated IL training activities, librarians must be equipped with not only knowledge of IL, but also expertise in subject disciplines, and teaching and facilitation skills. In particular, Pham (2008) claimed, Vietnamese IL instructors had insufficient knowledge of IL concept as well as needed skills to launch IL programs. Diep and Nahl (2011) justified, "Because a majority of librarians in Vietnam do not have a subject graduate degree, faculty consider them support staff rather than partners in teaching and curriculum development". And "that explained why librarians considered librarianship and subject knowledge two separate factors impeding the integration of IL into the curriculum".

Regarding to librarian's workload, the extension of IL integration across the university requires an adequate number of liaison librarians, IL trainers, learning skills advisors, and reference librarians getting involved in designing curriculum and learning assessment, and facilitating IL training activities. Meanwhile, there is a huge demand for continuing support from learners through their academic lives (Feast, 2003; Harrison \& Rourke, 2006).

Unlike the conventional role of material circulation, academic librarians are now expected to become professional trainers working in partnership with faculties and learning skills advisers to design the curriculum and deliver IL training activities (Harrison \& Rourke, 2006). Thus, they are required to improve their "teaching skills and learning facilitation" to meet new requirements (Bundy, 2004, p. 29). At a higher level, librarians take part in formulating educational policies and strategies, scaling IL sessions to successfully embed IL into the curriculum. Cathrine Harboe-Ree - the Monash University Librarian emphasized, "This new arrangement [IL integration] has provided an exceptional platform for information services staff and learning skills advisers to work with each other and with academic staff to ensure integration of learning skills and information literacy into coursework" (Monash University Library, 2007, p. 7). 


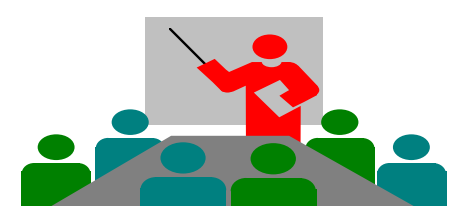

IL assessment methods

In Vietnam, IL assessment has not been aligned with students learning outcomes (Diep \& Nahl, 2011). Also, IL assessment has not been incorporated in academic policies as prerequisites for courses and subjects (Pham, 2008). Vietnamese libraries constructed IL assessment methods by themselves. IL assessment was in the forms of "observing in-class exercises, hands-on practice, and requesting verbal student feedback to evaluate performance.... is not equivalent to measuring of student learning outcomes" (Diep \& Nahl, 2011). A large number of library administrators admitted that they were not fully aware of IL competency standards.

IL competency standards have been widely applied in education institutions in Australia, America and the UK (Jackson \& Durkee, 2008). However, Parker (2003) stated, academics and librarians found it hard to determine what an information literate student looks like. He argued that IL assessment should be process based, rather than outputs-based evaluation. Citing and referencing skills, quality of academic sources and arguments demonstrated Parker (2003). In addition, scaling the percentage of IL assessment of out the overall subject assessment become chaotic and concerned many IL practitioners.

\section{Librarian-faculty collaboration}

Effective librarian-faculty collaboration is seen a critical successful factor for the integration of IL into curriculum. This partnership enables faculty and librarians effectively to meet students' learning needs (Pham, 2008). Grafsein (2002) reported, "Information literacy is not the unique and sole province of librarian [emphasized added], but it is an integral part of the objectives for every course on campus, and it requires administrative support for effective implementation". Frequent faculty-librarian interactions yielded in gaining understanding about student's information needs.

In Vietnam, the faculty-librarian collaboration is minimal In Vietnam and IL programs were perceived as solely library's responsibility (Diep \& Nahl 2011). The researchers noted, "The survey data supported qualitative findings with $89.4 \%$ of faculty and $81.3 \%$ of librarians ranking lack of collaboration between faculty and librarians as a great challenge or challenge"

Teacher-centred approach, passive/route learning style Initiating IL integration into the curriculum consequently shifts learning and teaching practices from passive/teacher-centred to active/independent/ resource-based/studentcentred approaches. In Vietnam, the Ministry of Education and Training implemented a credit system during 2006-2020. According to Dang (2006) and Lam (2006) cited in Diep \& Nahl (2011), the credit system aimed to transform learning and teaching methods from memorization to active learning approaches. However, research showed that teachercentred and passive/route learning is still dominant in classrooms in Vietnam (Diep \& Nahl, 2011; Nghiem, 2006; Pham, 2008). Students mainly rely on textbooks and lecture notes. Active/resources-based learning was not perceived as an effective method to broaden knowledge and enhance lifelong learning skills. Parr and Nguyen (2002) pointed out the differences between Vietnamese and Western pedagogical perspectives in terms of learning and teaching methods. To some extent, this paradigm shift shows the challenges facing learners and teachers when IL is embedded into the curriculum. 
Vietnamese Pedagogical
Pedagogical

Practices
Western

Practices

\begin{tabular}{|l|l|l|l|}
\hline \multicolumn{1}{|c|}{ Learning } & \multicolumn{1}{c|}{ Teaching } & \multicolumn{1}{c|}{ Learning } & \multicolumn{1}{c|}{ Teaching } \\
\hline - Heavily dependent & - Control and & - Process of & - Stimulate the desire to \\
on teacher & responsibility for & discovery & discover \\
help/guidance & student progress & - Find an answer & - Encourage possibilities \\
- Gain new & - Teaching based & - Self directed & - Facilitator \\
knowledge through & on a set text & - Proactive & - Develop confidence of \\
textbooks and & - Provision of & - Time consuming & learner to enquire and \\
teacher input & model answers & - Research based & question \\
- Reluctance to & for memorization & - Integrated & - Process of learning is as \\
question what is & - Performance in & development & valuable as outcome \\
written in text or & exam the & - Collegiate & - Teach research skills \\
teacher & measure of & - Constant life- & - Indicate multiple sources of \\
explanation & student & long process & materials \\
- Focus on marks in & performance/achi & & - Learner centred \\
exams & evement & & - Constantly changing \\
& & & process with learners \\
\hline
\end{tabular}

Figure 2: Vietnamese and Western Pedagogical Practices

Source: (Parr \& Nguyen, 2002, p. 3)

Contents and forms of IL training activities

It is unrealistic to initiate IL integration, if IL training contents are poor and still at a basic level. Librarians are required to gain knowledge in specific disciplines and be capable of delivering IL skills training classes ranging from novice to expert level.

However, what Vietnamese students benefit from IL training programs is limited to introductions to library resources and circulation policies, OPAC searching skills (Pham, 2008). In addition, IL training courses are still scattered, unsystematic, infrequent and at a basic level. Hickok stated that "Nearly every library I visited [in Vietnam] does offer some forms of orientation training, such as tours, PowerPoint presentations, etc. But continual user is not as frequent. Similarly, Diep \& Nahl (2011, p. 340) revealed that "Nearly $98 \%$ of librarians reported focusing on teaching how to use library services and the OPAC.

Table 2: IL Training Programs at Eight Vietnamese Universities

\begin{tabular}{|c|l|l|l|}
\hline Seq. & \multicolumn{1}{|c|}{ Training topics } & \multicolumn{1}{c|}{ Institutions } & \multicolumn{1}{c|}{ Websites } \\
\hline 1 & $\begin{array}{l}\text { - Information searching skills } \\
\text { - Plagiarism and copyright } \\
\text { related issues } \\
- \text { Citing and referencing }\end{array}$ & Hoa Sen University & $\begin{array}{l}\text { http://thuvien.hoasen.edu. } \\
\text { vn/kttt }\end{array}$ \\
\hline 2 & $\begin{array}{l}\text { - Big6 research process } \\
- \text { Citing and referencing \& } \\
\text { Endnote software }\end{array}$ & Hanoi University & $\begin{array}{l}\text { http://lic.hanu.vn/51/tai- } \\
\text { lieu-lop-kien-thuc-thong- } \\
\text { tin.html }\end{array}$ \\
\hline 3 & - No information & $\begin{array}{l}\text { Hanoi Foreign Trade } \\
\text { University }\end{array}$ & $\begin{array}{l}\text { http://thuvien.ftu.edu.vn/si } \\
\text { tes/Home.aspx }\end{array}$ \\
\hline 4 & - No information & Hanoi Law University & http://lib.hlu.edu.vn/ \\
\hline 5 & - Library orientation & $\begin{array}{l}\text { Water Resource } \\
\text { University Library }\end{array}$ & http://lib.wru.edu.vn/ \\
\hline 6 & - No information & $\begin{array}{l}\text { National Economics } \\
\text { University }\end{array}$ & http://lib.neu.edu.vn/opac \\
\hline
\end{tabular}




\begin{tabular}{|c|c|c|c|}
\hline 7 & - Information searching skills & $\begin{array}{l}\text { Ho Chi Minh } \\
\text { University of Natural } \\
\text { Science }\end{array}$ & $\begin{array}{l}\text { http://gralib.hcmuns.edu.v } \\
\text { n/bantin/bt812/Bai3.pdf }\end{array}$ \\
\hline 8 & $\begin{array}{l}\text { - OPAC searching skills } \\
\text { - Effective internet searching } \\
\text { skills } \\
\text { - Online database searching } \\
\text { skills } \\
\text { - Web } 2.0 \text { for learning and } \\
\text { researching purposes } \\
\text { - Citing and referencing skills \& } \\
\text { Zotero software }\end{array}$ & Can Tho University & $\begin{array}{l}\text { http://www.Irc.ctu.edu.vn/i } \\
\text { mages/Cac\%20lop\%20K } \\
\text { NTT\%20tai\%20TTHL.pdf }\end{array}$ \\
\hline
\end{tabular}

Curriculum overload

The final challenge is overloaded curriculum when IL is embedded. Research conducted by Parker showed that, the curriculum has been crowed in terms course contents in education institutions in Australia (Parker, 2003, p. 224). While IL skills are required to be integrated into class activities, it's necessary to remain course structures and workloads for students and lecturers. In addition, faculties are in charge of many concurrently duties such as teaching activities, administrative works, publications, and participations to conferences, workshops.... Therefore, they have limited time for reflecting on their teaching methodology as well as IL embedment initiatives (Feast, 2003, p. 88).

In Vietnam, the Ministry of Education and Training issued the policy which requires institutions to reduce the number of credits from 210 to 120 as so to increase self-study time for learners both faculties and librarians expressed their concern about overloaded curriculum when aligning IL into the curriculum. In particular, both librarians and faculties ranked curriculum overload as most challenges seventh and fifth $(81.1 \%)$ respectively (Diep \& Nahl, 2011).

\subsection{The significance of IL integration to the enhancement of student's lifelong learning skills}

Lifelong learning objective has recently been central to education institution missions and one of the graduate attributes (Bundy, 2004; Feast, 2003; Monash University Library, 2009; University of Guelph, 2006), while "IL is the key foundation to lifelong learning" (Feast, 2003, p. 82). According to Wingspread Group on Higher Education (1993), "Although information literacy can be learned, but it must be taught and practiced, not merely absorbed as a result of unplanned academic experience". Therefore, IL initiatives need a systematic and holistic approach rather than segmented teaching efforts by librarians and faculties to promote collaborative efforts across the university (Jackson \& Durkee, 2008).

Another catalyst for IL integration is exposed to diverse and abundant information available on the Internet. Farmer (2003) found that digital information doubles every two years. Also, Feast (2003, p. 81) states "The amounts of information have multiplied many times in recent years. Technological advances have made knowledge become outdate quickly". Comparing to printed materials (peer-reviewed sources), digital information is characterized by overloading, uncertainties and ambiguities. People are now able to upload any realizable and unrealizable, accurate and inaccurate, authorized and unauthorized, update and outdate biased and unbiased information on the Internet. Thus, students are required to be more critical when making their information choices. These external pressures compel education institutions to rethink about the relevance of their training programs. Learners should be equipped with sufficient IL skills for their learning purposes during academic lives and for their problem-solving efficacy in professional lives. IL integration is, therefore, considered an essential strategy to remain teaching and learning activities relevant to rapid changes in the surrounding environment. 


\section{IL integration Strategies}

\subsection{Top-down management approach}

IL needs to be central to institutions missions and incorporated into strategic plans. Also, lifelong learning objective should be recognized as one of the desirable graduate attributes (Abbott \& Peach, 2000; Feast, 2003; Monash University Library, 2009; Rockman, 2004). IL policy should be formulated to reinforce IL integration initiatives at all levels and to promote collaborative processes across the university (University of Wollongong, 2013).

Leaders and managers strongly commit and champion the integration of IL into curriculum at all organizational levels. In this context, the transformational leader is suggested to be an appropriate approach to inspire and motivate faculties, librarians, and learning skills advisers to initiate this change. IL trainers actively take part in leading IL integration, if they understand the significance of such changes, and find themselves as integral part to lead the change (Hitt, Black, Porter, \& Hanson, 2007, p. 394).

\subsection{Assignment design reflects the need for IL skills}

"Assignment design reflects the need for IL skills" strategy starts at the curriculum level. Theoretically, assignments should be designed in the way that "facilitates a fruitful interaction between students and information resources" (Kavulya, 2003, p. 221). Academics work closely with librarians and learning skills advisers to integrate core IL competency standards into assignment objectives. In particular, the researcher proposes a sample process for assignment design. This initiative bases on hand-on experiences of the Reference Services Division, Monash University Library.

At Monash University, a set of assignments were designed to enable students to develop their IL skills from the basic to advanced levels. Student's assignments include 1) individual tasks such as critical reviews, short and long essays, presentations, and 2) group works. The formulation of assignment objectives aims to enable students to:

+ Demonstrate in-depth understanding about the research topic,

+ Develop critical thinking abilities through the quality of arguments,

+ Have opportunities to explore a wide range of sources supporting the research topic. So that, apart from text books they are able to read widely to comprehend contemporary issues related to the research topic (Jackson \& Durkee, 2008),

+ Demonstrate their abilities to recognize value of information, explore information needs, search information effectively, locate and retrieve information sources, and effectively evaluate information. For example, to effectively evaluate information, students are required to assess five criteria: currency, authority, coverage, objectivity, and accuracy of the retrieved information. These criteria base on Information Literacy Competency Standards developed by the American Library Association (Jackson \& Durkee, 2008, p. 94).

Learners were experienced IL learning through three stages. At the first stage, students are requested to complete and assignment which was designed for IL beginners. Students had to find six academic articles on online databases and then complete an annotated writing, and a 600 word long critical review. These pieces of writing tasks encouraged students to evaluate the relevance, reliability, shortcomings of the retrieved articles (Andrew \& Patil, 2007 , p. 256). During this stage, freshmen needed support from librarians, learning skills advisors, lecturers, and tutors to conduct their information searching. These tasks aimed to help learners to broaden background understanding about the research topic (Andrew \& Patil, 2007, p. 257). It was also the opportunity for students to practice searching on OPAC and online academic databases searching, developing writing skills, and getting acquainted with citing and reference skills.

In the next stage, students were given the second assignment at the intermediate IL level. The writing essay was about 1500 to 2000 word long. Students were expected to 
demonstrate their higher critical thinking abilities. Purposes of the assignment were to enable students to gain a proficiency in library catalogue and databases searching skills, information evaluation. Required academic articles for the assignment ranged from 10 to 15 .

The third assignment was either a longer essay, or a presentation which can be a group or individual project. Assignment objectives were to assisting students with gaining advanced IL skills. The amount of words for the third writing task varied from 4000 to 5000 words (Andrew \& Patil, 2007). The assignment aimed to encourage students to read broadly, and form complex and constructed arguments. Like Andrew and Patil (2007, p. 256) advised, the third assignment should challenge student's abilities to address "problem statement, position statement, analysis of existing and proposed solutions to the problem and their own solutions". These authors stress on the aspect of ethical use of information reflected in the assignment.

This sample assignment design process is seen a more feasible and practical strategy for the integration of IL into the curriculum. It requires collaborative efforts among academics, librarians, learning skills advisors to develop assignment objectives. The application of the UK IL Competency Standards is strongly recommended assess student's IL progress.

\subsection{IL is assessed as part of assignment assessment}

Academic policy makers, course coordinators, librarians and learning skills advisers work collaboratively to identify the percentage of IL assessment out of the overall assignment assessment. Harrison and Rourke (2006) recommended that the IL assessment should be from $10-15 \%$ of the final grade of each subject. Since IL assessment focuses on the progress, rather than an output-based evaluation. So "portfolios of IL skills or attributes achieved rather than a 'pass' in IL which means very little" as Parker (2003, p. 226) suggested. IL trainers should employ IL standard frameworks to develop IL assessment criteria as mentioned above.

\subsection{Capacity building}

Consolidate IL knowledge and skills are necessary to librarians, faculties, learning skills advisers. There is knowledge gap among both faculties and librarians in terms of the values of IL integration. While faculties probably need to deepen their understanding about IL concept and the significance of IL integration, teaching and facilitation skills and knowledge of curriculum design are necessary to librarians. Education institutions should organize professional development activities such as short course training, conferences, workshops, seminars, meetings, and other community of practices that enable IL trainers to share handon experiences and knowledge.

\subsection{Strengthening the faculty-librarian collaboration}

Faculty-librarian partnership is the cornerstone for the integration of IL into the curriculum. They are key actors who frequently engage with student learning activities (Hine et al., 2002). Instead of conducting standalone IL programs, this practice now requires collaborative efforts meet the needs of large number of students. Not only do freshmen need IL skills, but also final year students, honour students, lecturers, researchers and those who desire to master high advanced IL skills. Faculty-librarian collaboration enables librarians to learn more about course objectives, assessment instruments, information needs. In return, this partnership creates more opportunities for faculties to understand information resources appropriate to their students, information literacy standards, and information searching strategies. The Figure 4 illustrates this partnership. 


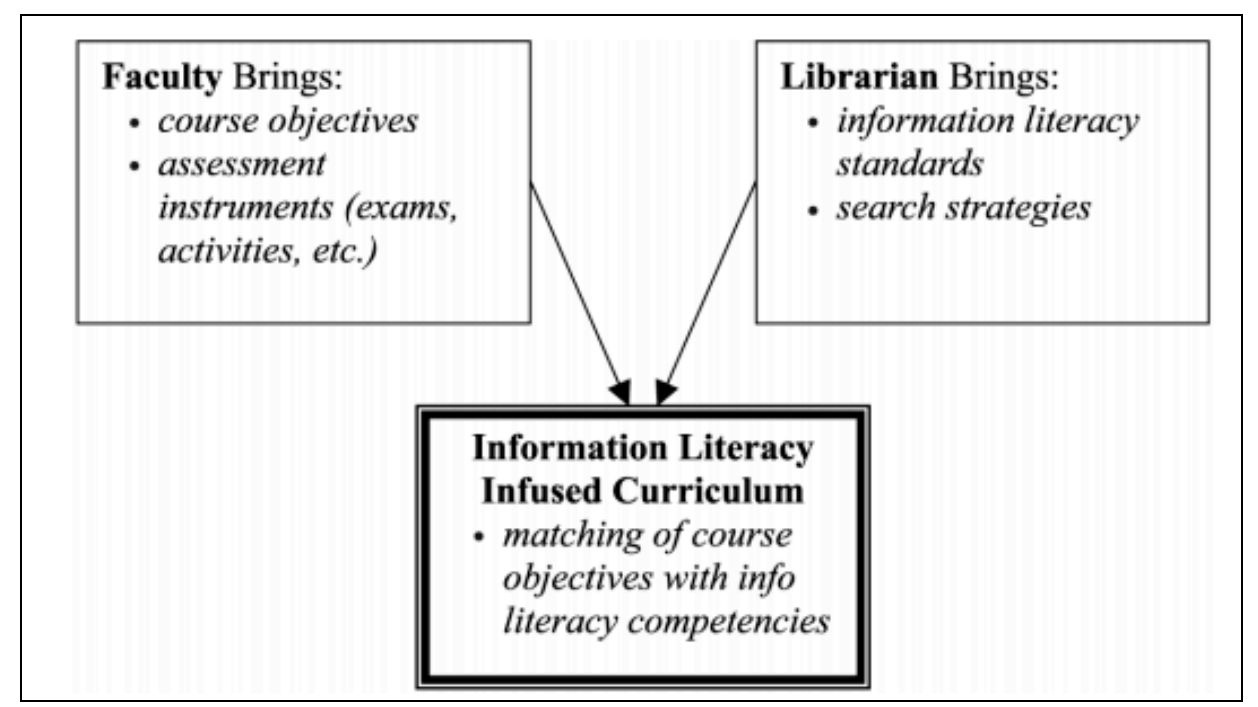

Figure 3: Faculty-librarian Partnership

Source: (Fiegen, Cherry, \& Watson, 2002, p. 316)

\subsection{Enrich IL training contents}

IL integration into the curriculum requires diverse and rich IL training contents (Fiegen et al., 2002). Students need a continual IL training through their academic lives, so training contents must be varied from novice to advanced level. Also, IL courses designed for specific disciplines compel librarians to incorporate relevant discipline-related contents into IL training activities.

\section{Conclusion}

IL integration into the curriculum has become a common trend in the higher education. IL is central to the institution missions. Lifelong learning is considered one of the core desirable graduate attributes. Learners are expected to become information literate person to cope with diverse and abundant information available in the Internet. Curriculum renovation is thus essential in this context. This study uncovered the essence of IL integration into curriculum. Eight common challenges were identified and six strategies were proposed to develop holistic IL training programs for tertiary institutions. The paper also indicates the significance of IL integration into curriculum to the enhancement of student's lifelong skills.

\section{References}

Abbott, W., \& Peach, D. (2000). Building Info-skills by Degrees: Embedding Information Literacy in University Study.

Andrew, T., \& Patil, R. (2007). Information literacy for first-year students: an embedded curriculum approach. European Journal of Engineering Education, 32(3), pp. 253-259.

Australian Bureau of Statistics. (1998). Australian's literacy skills put to the best: the survey of aspects of literacy. Retrieved viewed on June 5, 2009, from ABC

http://www.abs.gov.au/AUSSTATS/ABS@.NSF/Previousproducts/1301.0Feature\%20A rticle401998?opendocument $\&$ tabname $=$ Summary $\&$ prodno $=1301.0 \&$ issue $=1998 \&$ num $=$ \&view=

Australian Library and Information Association. (2006). Statement on information literacy for all Australians. Retrieved viewed on June 10, 2009, from ALIA http://www.alia.org.au/policies/information.literacy.html 
Barnett-Page, E., \& Thomas, J. (2009). Methods for the synthesis of qualitative research: a critical review. NCRM Working Paper. NCRM. (Unpublished). NCRM Working Paper.

Brophy, J., \& Bawden, D. (2005). Is Google enough? Comparison of an internet search engine with academic library resources. Paper presented at the Aslib Proceedings: New Information Perspectives.

Bundy, A. (2004). Australian and New Zealand Information Literacy Framework: Principles, Standards and practice (pp. p. 52 pgs). Adelaide, Australia: Australian and New Zealand Institute for Information Literacy.

Catalano, A. (2013). Patterns of graduate students' information seeking behavior: a metasynthesis of the literature. ournal of Documentation, 69(2), 243 - 274.

Derakhshan, M., \& Singh, D. (2011). Integration of information literacy into the curriculum: a meta-synthesis. Emerald Group Publishing Limited, 60(3), 218-229.

Diep, K. C., \& Nahl, D. (2011). Information Literacy Instruction in Four Vietnamese University Libraries. Elsevier, 43(4), pp. 198-206.

Duke, T. S., \& Ward, J. D. (2009). Preparing information literate teachers: A metasynthesis. Library \& Information Science Research.

Farmer, L. F. S. (2003). Faciliating faculty incorporation of information literacy skills into the curriculum through online instruction. Reference Services Revew, 31(4), 307-312.

Feast, V. (2003). Integrating information literacy skills into business courses. Reference Services Revew, 31(1), 81-95.

Fiegen, A. M., Cherry, B., \& Watson, K. (2002). Reflections on collaboration: learning outcomes and information literacy assessment in the business cirruculum. Reference Services Revew, 30(4), 307-318.

Grafstein, A. (2002). A discipline-based approach to information literacy. The Journal of Academic Librarianship, 28(4), 197-204.

Grant, M., \& Berg, M. (2004). Information Literacy Integration in a Doctoral Program. Behavioral Social Sciences Librarian 22(1), 115-128.

Harrison, J., \& Rourke, L. (2006). The benefits of buy-in: integrating information literacy into each year of an academic program. Reference Services Review, 34(4), pp. 599-606.

Hine, A., Gollin, S., Ozols, A., Hill, F., \& Scoufis, M. (2002). Embedding information literacy in a university subject through collaborative partnerships Psychology Learning and Teaching, 2(2), pp. 102-107

Hitt, M. A., Black, J. S., Porter, L. W., \& Hanson, D. (2007). Management. NSW: Pearson Australian Education.

Huffman, R. S. (2013). How to Integrate Information Literacy into Higher Education Curriculum, June 20, 2013, from http://big6.com/pages/lessons/articles/how-tointegrate-information-literacy-into-higher-education-curriculum.php 
IFLA. (2005). Beacons of the Information Society: The Alexandria Proclamation on Information Literacy and Lifelong Learning, June 17, 2013, from

http://www.ifla.org/publications/beacons-of-the-information-society-the-alexandriaproclamation-on-information-literacy

Jackson, S., \& Durkee, D. (2008). Incorporate information literacy into the accounting curriculum. Accounting education: an international journal, 17(1), 8397.

Johnson, B., \& Webber, S. (2003). Information literacy in higher education: a review and case study. Studies in Higher Education, 28(3), 335-352.

Kavulya, J. M. (2003). Challenges facing information literacy efforts in Kenya: a case study of selected university libraries in Kenya. Library Management, 24(4/5), 216 - 222.

Kuhlthau, C. C. (1987). Information Skills for an information society: a review research. An ERIC Information analysis product, ERIC Digest.

Lankshear, C., \& Knobel, M. (1998). Critical Literacy and New Technologies. Paper presented at the the Annual Meeting of the American Educational Research Association, San Diego.

Monash University Library. (2007). Annual report 2007 (pp. 48). Melbourne: Monash University.

Monash University Library. (2009). Advancing scholarship: Strategic plan 2009-2011; 2009 Strategic priorities (pp. 2). Melbourne: Monash University.

Moore, P. (2002). An Analysis of Information Literacy Education Worldwide. White paper prepared for UNESCO, the U.S. National Commission on Libraries and Information Science, and the National Forum on Information Literacy, for use at the Information Literacy Meeting of Experts. from Prague, The Czech Republic www.nclis.gov/libinter/infolitconf\&meet/moore-fullpaper.pdf

Nghiem, H. X. (2006). Difficulties in Implementing Information Literacy Programs at Colleague of Social Sciences and Humanities (Vietnam National University, Hanoi). Paper presented at the Paper presented at the Interational Conference of Information Literacy (ICIL), Kuala Lumpur, Malysia.

Online Computer Library Center. (2005). Perceptions of Libraries and Information Resources: A Report to the OCLC Membership, June 15, 2013, from http://www.aect.org/publications/whitepapers/2010/informationhabits.pdf

Parker, J. (2003). Putting the pieces together: information literacy at The Open University. Library Management, 24(5), pp. 223-228.

Parr, G., \& Nguyen, C. H. (2002). Parr, G., \& Chung, N. H. (2002). Western Practice Vietnamese Praxis: "Where do we study and learn? We study and learn at school, college or university. We study and learn from books. We study and learn together from each other.". Paper presented at the Internationl Association of School Library, Malaysia.

Paterson, B. L., Dubouloz, C. J., Chevrier, J., Ashe, B., \& Moldoveanu, M. (2009). Conducting Qualitative Metasynthesis Research: Insights from a Metasynthesis Project. International Journal of Qualitative Methods, 8(3). 
Pham, H. X. (2008). Challenges Facing the Implementation of Information Literacy (IL) Programs in Vietnamese Universities. Paper presented at the IFLA/ALP INDONESIAN WORKSHOP ON INFORMATION LITERACY, Bogor, Indonesia.

Pham, H. X. (2012). Student's Information Seeking Behaviors - Problems And Impacts. Internationalization Studies, 1.

Rockman, I. F. (2004). Integrating information literacy into the higher education curriculum: practical models for transformation. San Francisco, CA: Jossey-Bass.

Saunders, M., Lewis, P., \& Thornhill, A. (2009). Research methods for business students. Harlow, England: Pearson Education.

SCNUL. (2007). The Seven Pillars of Information Literacy model. Retrieved viewed on 23 May, 2009, from Society of College, National and University Libraries http://www.sconul.ac.uk/groups/information_literacy/sp/model.html

University of Guelph. (2006). University of Guelph Library Integrated Plan: 2006-2010 (pp. pp. 17). Ontario, Canada: University of Guelph.

University of Wollongong. (2013). Information Literacy Integration Policy, June 20, 2013, from http://www.uow.edu.au/about/policy/UOW026890.html

Wang, L. (2011). An information literacy integration model and its application in higher education. Reference Services Review, 39(4), 703 - 720.

Wang, X. (2010). Integrating information literacy into higher education curricula : an IL curricular integration model. (PhD thesis), Queensland University of Technology, Australia.

Wingspread Group on Higher Education. (1993). An American imperative: higher expectations for higher education. Racine, Wisc.: Johnson Foundation.

\section{Biographical note}

Hoan undertook a formal bachelor degree in Library and Information Science at Hanoi Culture University. He was then offered two scholarships to complete a master of Educational Leadership and Management at RMIT University during 2005-2006, and a master of Information Management and Systems Professional at Monash University, Melbourne, Australia during 2007-2009. Hoan has nearly 10 years working in the library and information services and AusAID alumni network development, and is currently a Library Manager at International School - Vietnam National University. He was interested in information literacy since 2005. Since then, he has placed enormous efforts in studying how information literacy advances lifelong learning skills for students. His long-term goal is to develop a holistic and systematic IL program at International School by integrating IL into the curriculum. Besides, Hoan is also keen on studying knowledge management, and IT and Business alignment. His career objective is to contribute his knowledge and skills to the innovation of academic libraries, and more broadly, quality of learning, teaching and researching activities in academic settings in Vietnam. 